\title{
Improvement of the methods of state cadastral assessment of agricultural lands while accounting the expenses for bringing a land plot to the state of maximum use efficiency
}

\author{
Ekaterina Podryadchikova ${ }^{1, *}$ and Larisa Gilyova ${ }^{2}$ \\ ${ }^{1}$ Industrial University of Tyumen, Department of Geodesy and Cadastral Activities, 625001, Tyumen, \\ Russia \\ ${ }^{2}$ Omsk State Agrarian University named after P.A. Stolypin, Department of Land Management, \\ 644008, Omsk, Russia
}

\begin{abstract}
The article discusses the problems and substantiates the need to take into account environmental factors in the state cadastral assessment of agricultural lands. A Methodology for calculating the environmental factor is presented. Such factor is considered as the economic equivalent of the restoration and improvement of the fertility in terms of expenses for bringing a land plot to the state of maximum use efficiency; the aim of the process is eliminating the negative consequences of an irrational use of land plots. The calculation of the expenses for bringing a land plot to the state of maximum use efficiency was carried out on the example of a land plot located in the Moskalensky District of the Omsk Region. Recommendations are given for improving the methodology for calculating the cadastral value of agricultural lands as regards farmlands by taking into account the level of expenses for bringing a land plot to the state of maximum use efficiency.
\end{abstract}

\section{Introduction}

Agricultural lands are rightfully considered a strategic object of vital activity, the basis of the economic and environmental well-being of a country, as well as of each region and municipality taken separately. Of all the existing land categories, only agricultural lands are directly used for growing products, being at the same time a natural resource. At the present time, the question of the rational use of territories for agricultural production, in particular increasing their economic efficiency while observing environmental priorities, has acquired particular relevance. It should be borne in mind that a special property of land is its limited space; to preserve and ensure soil productivity, appropriate measures must be taken, including the state cadastral assessment of agricultural land plots in order to establish a fair tax on the cadastral value, taking into account the economic use efficiency.

The exploitation of agricultural natural resources is a complex system that includes the human impact on the soil, vegetation and surface waters on the one hand, and the response

\footnotetext{
*Corresponding author: podryadchikova_ed@mail.ru
} 
of the natural system to these impacts on the other. The deterioration of environmental factors in agriculture has a negative impact on the economy of the agro-industrial sector. So, with low soil fertility, far more expenses are required to obtain a yield unit than with high one. This leads to higher production costs; in addition, in some cases, high productivity of the land is simply impossible due to poor soil structure due to salinization, waterlogging, erosion, pollution with heavy metals and pesticides. The elimination of negative environmental consequences often requires huge resources that significantly exceed the expenses for maintaining and protecting the environment. As a result, production decreases, as well as the profitability of individual enterprises and of the industry as a whole [1].

The only way to preserve soil quality is to introduce some economic mechanisms for the environmentalization of land use, the most important of which is environmentally oriented land assessment. Rational land assessment on a soil-ecological basis is capable of solving not only environmental, but also economic problems in the field of land use [2].

All over the world, agriculture is propped up by the state budget, being provided with tax breaks and many other benefits. The existing objective difficulties of the agrarian economy are due to its specifics, which are primarily associated with seasonality and great dependence on natural and climatic conditions; such difficulties are forcing Russia to implement government support measures taking into account the understanding that rapidly developing agricultural production contributes to the growth of the socio-economic development of the country and its regions [3].

The active efforts of the state in organizing the use of agricultural lands are aimed at: updating the current regulatory and legal framework; creating a unified federal information system on agricultural lands; certificating the plots; approving the criteria for the improper use of agricultural lands; ensuring protection against unjustified changes in the type of permitted use, which will provide for the identification of unused and unusable lands; ensuring their economically efficient and sustainable development. Protection of lands is closely related to the concept of the rationality of their use, but to this day this concept is not legally codified. At the present time, meeting the requirements for the protection of lands (especially agricultural lands) is entrusted to the owners of the lands themselves, who at the same time are supposed to honour their obligations for their rational use [4].

The topic of the state cadastral assessment of agricultural lands is represented in various aspects and methodological approaches in many works of domestic scientists and practitioners: D.S. Bulgakov, B.E. Bondarev, S.N. Volkov, A.A. Varlamov, A.L. Ivanov, I.I. Karmanov, S.A. Shapovalov, V.V. Vershinin, S.I. Nosov, A.V. Pylaeva, A.V. Sevostyanov, A.A. Murasheva, I. Yu. Savin, P.M. Sapozhnikov, O.A. Skufinsky, V.S. Stolbovoy, V.A. Makht, V.A. Rudi, N.V. Osintseva, O.K. Ogleznev and others. Most of the scientific reviews and practical results are devoted to the consideration of problems associated with the determination of the cadastral value of agricultural lands as regards the application of methodological provisions while determining the cadastral value and analysing the results.

The result of the state cadastral assessment - i.e. the cadastral value of a land plot - is the basis for taxation; budgets are funded at all levels by collecting taxes on land, the fair amount of which helps to reduce social and economic tension in the society.

Thus, the economic efficiency of the cadastral assessment of agricultural lands consists in replenishing the budget of a municipality through taxes and loan fees [5]. Tax rates for agricultural lands amount to $0.3 \%$, which is significantly lower than the rates established for other categories of land $(1.5 \%)$. This allows the land owner to ensure the maximum economic benefit with minimum taxation.

The relevance and timeliness of the present research is justified by the above-mentioned provisions on the need and relevance of the assessment of agricultural lands, the 
significance of these lands for the welfare of the state and the population, and the safeguard of their rational use; the aim of the research is to improve the provisions of the methodology for the state cadastral assessment of agricultural lands and to justify the calculation of the cadastral value by taking into account the expenses for bringing a land plot to the state of maximum use efficiency for the implementation of the provisions of rational land use.

\section{Materials and Methods}

Object of the research are agricultural land plots located in the Omsk Region, the largest agricultural area in Western Siberia. It should be noted that agriculture in the Omsk Region is carried out in difficult agro-climatic conditions: sharp continentality, lack of precipitation, dry air, long cold winters and hot summers. The soil cover of the region is distinguished by a wide variety of types and kinds of soil, each having its own characteristics in terms of quality and level of natural fertility. Latitudinal zoning, changing from north to south, is clearly expressed in the distribution of soil types over the territory of the Region.

As of January 1, 2021, the total area of agricultural lands within the boundaries of the Omsk Region amounts to 7,587.1 thousand hectares, or $53.8 \%$ of its total area. Taking into account the unchanged configuration of the borders of the Omsk Region over the last 20 years as well as the data of the environmental passport, a steady tendency can be observed towards the reduction of the area of agricultural lands and an increase in the area of unused or already unusable lands. From 2002 to 2020, the reduction of agricultural lands amounted to 1,593 thousand hectares, or $18 \%$. The main reason for the reduction in the area of agricultural lands is the conversion of lands into other categories.

Farmlands occupy 6,721.1 thousand hectares $(47.62 \%)$ in the structure of the category of agricultural lands of the Omsk Region, including 4,156.6 thousand hectares of arable lands, 175.9 thousand hectares of fallow lands, 26, 5 thousand hectares of perennial plantations, 1,096.2 thousand hectares of hayfields, and 1,265.5 thousand hectares of pastures. As of the end of 2020, the area of unused arable lands amounted to 525.8 thousand hectares, of which 293.1 thousand hectares have not been used for more than 10 years. The consequences of the non-use of lands are their overgrowing with shrubs, the development of degradation processes and a decrease in their natural fertility. About 19 billion rubles, or 3,795.8 million rubles a year, should be spent to carry out works aimed at introducing unused arable lands into the farming turnover [6].

The most important component of the economic mechanism for regulating land relations, the involvement of agricultural land in the turnover of land plots is the state cadastral assessment of land as a complex of legal, administrative and technical measures aimed at establishing the cadastral value of land plots recorded in the unified state register of real property to secure the payment for land use in the form of land tax and loan fees[7].

In 2020, state cadastral assessment of 96,772 agricultural land plots was carried out on the territory of the Omsk Region, taking into account the peculiarities of the agricultural and agro-climatic zoning of the territory.

The procedure for conducting state cadastral assessment consists in a set of actions, including the following: 1) the decision to carry out state cadastral assessment; 2) the determination of the cadastral value and the preparation of the report on the results of the state cadastral assessment; 3) the approval of the results in determining the cadastral value [5].

The determination of the cadastral value of agricultural land plots classified in the "agricultural use" segment, calculation code 01:000, 01:010, 01:020, 01:030, 01:031, 01:032, 01:040, 01:041, 01:050, 01:051, 01:060, 01:070, 01:080, 01:081, 01:083, 01:084, 
01:085, 01:086, 01:120, 01:121, 01:140, 01:141, 01:142, 01:160, 01:170, 01:171, 02:022 was carried out using the land rent capitalization method, which takes into account gross income, the expenses for the cultivation and harvesting of agricultural products, standard yield and correction factors for soil properties.

$$
C V F L=\frac{\frac{Y_{r s} \cdot K_{s} \cdot A P}{A P_{b} \cdot K_{1} \cdot K_{2} \cdot K_{3} \cdot K_{4}} \cdot P-E_{C}}{R_{c}}
$$

where:

$C V F L$ - the cadastral value of farmlands;

$Y_{r s}-$ standard yield (in $\mathrm{q} / \mathrm{ha}$ ) of grain crops on the reference soil $(33.2 \mathrm{q} / \mathrm{ha})$;

$K_{c}$ - the coefficient of conversion to the level of yield with intensive cultivation technology (1.4);

$A P$ - the value of the local agro-ecological potential for grain crops;

$A P_{b}$ - the basic value of the agro-ecological potential for grain crops (10);

$K_{1}-K_{4}$ are correction coefficients:

$K_{l}$ - the humus content in the arable layer;

$K_{2}$ - the thickness of the humus horizon;

$K_{3}$ - the content of physical clay in the arable layer;

$K_{4}-$ negative soil properties.

$P$ - the projected selling price of the products of the evaluated crop in the constituent entity of the Russian Federation, rubles/q;

$E_{c}$ - the expenses for the cultivation and harvesting of agricultural products;

$R_{c}$ - the capitalization ratio.

The values of the coefficients $K_{1}-K_{3}$ are determined using the following information on soil characteristics: the content of humus, the thickness of the humus horizon and the content of clay in the arable layer; such data are contained in the Unified State Register of the Soil Resources of Russia.

The coefficient $K_{4}$ - i.e. negative soil properties - was considered equal to 1 , since there is no exact information on the negative soil properties in each subzone; this, according to the authors of the article, is absolutely unacceptable, because it significantly biases the cadastral value of land plots.

When determining pricing factors, due to the lack of complete and reliable data as of the date of the assessment, the granulometric composition of soils (mechanical composition), rockiness, salinity, alkalinity, alkalis in terms of the thickness of the supra-natric horizon, carbonate content, compaction, waterlogging, the presence of inconveniences (the degree of indented relief), the diversity of the soil cover in relation to each specific plot were not taken into account.

To determine the expenses for the cultivation and harvesting of agricultural products, only the data of the previous round of the state cadastral assessment of agricultural lands were used, while technological maps were not used, which also influenced the assessment results.

For the calculations, the capitalization ratio was established at an average value of $12.85 \%$, obtained from the average values of the capitalization ratios of land plots of arable lands, fodder lands, perennial plantations and fallow lands. The projected selling price of each agricultural crop that can be grown in the Omsk Region was determined on the basis of statistical information.

Based on the above indicators, which are deemed necessary to determine the cadastral value, it should be noted that they are significantly averaged in relation to the specific subject, whereas the cadastral assessment is carried out for each land plot recorded in the 
Unified State Register of Real Properties.

In 2018 - 2020, apart from the Omsk Region, another 20 constituent entities of the Russian Federation carried out a state cadastral assessment of agricultural lands according to the new Methodology; while carrying out this work, significant problems arose, as noted by P.M. Sapozhnikov, V.A. Makht, V.A. Rudi and other scientists and practitioners: there is no soil-cartographic material; the pointlessness of dividing the surface within the boundaries of a land plot according to the types of permitted use is not methodically fixed; the exclusion of fallow lands from the assessment, due to the lack of information on the use of the farmlands in the list, is not methodically fixed; the determination of the minimum indicators of the cadastral value of farmlands, defined as the cost of land surveying in the constituent entity of the Russian Federation, require specifics for the Northern regions, where the cost of land surveying exceeds the average cadastral value for municipal areas [8.9].

It is the authors opinion that, in addition to the above-mentioned problems, the environmental factor was not taken into account as well; such factor reflects the qualitative characteristics of the agricultural land plot (the degree of development of negative processes such as erosion, desertification, paludification, waterlogging, pollution) and regulates the need to improve and restore the natural fertility of the land plots, motivating the owners to improve them. For this purpose, the authors propose to calculate the economic equivalent of restoring and improving fertility as the expenses for bringing a land plot to the state of maximum use efficiency; these expenses are aimed at eliminating the negative consequences of the irrational use of land plots.

The methodology for calculating the environmental factor can be presented in the form of the sequential execution of the following stages:

Stage 1 . At the preparatory stage, through field or office surveys, agricultural land plots or parts of them are identified as needing to be brought to a state of maximum use efficiency. Two main ways to identify such land plots should be considered: as a result of the monitoring outcomes on the state of land or by means of a declarative method, when a declaration is filled in by the right holder of the land plot.

Stage 2. Development of an action plan to bring lands to the state of maximum use efficiency. Determination of the degree of negative impact of each factor, of the reasons that caused disturbances, of the percentage of decrease in soil fertility and increase in unit costs for maintaining soil fertility.

Stage 3. Collection of information on the expenses for bringing the land plot to the state of maximum use efficiency. Analysis of information on the cost of seeds, organic and mineral fertilizers, as well as mechanical tillage. It is recommended to use the data of the report form on the financial and economic state of the agro-industrial sector of the area, as well as data from tax inspections and from the Federal State Statistics Service regarding the current year.

Stage 4. Calculation of the expenses for bringing the land plot to the state of maximum use efficiency; this should constitute the environmental component of the cadastral value, according to the formulas proposed by the authors of the article.

The calculation of expenses should be carried out by adding the expenses for restoring and improving fertility, lost profits and the expenses for conducting an agrochemical survey according to the following formula:

$$
E_{\text {eff }}=E_{r i}+L P+E_{\text {sur }}
$$

where:

$E_{\text {eff }}$ - the expenses for bringing the land plot to the state of maximum use efficiency, in rubles;

$E_{r i}-$ the expenses for restoring and improving the fertility, in rubles; 
$L P$ - the lost profit, in rubles;

$E_{\text {sur }}$ - the expenses for conducting an agrochemical survey, in rubles.

$$
E_{r i}=\left(R_{s} \cdot P_{S}+R_{f} \cdot P_{f}+C_{t i l}\right) \cdot S
$$

where:

$E_{r i}-$ the sum of the expenses for restoring and improving the fertility;

$P_{s}$ - the price of seeds, in rubles/t;

$R_{s}$ - the recommended seeding rate of the seeds, in $\mathrm{t} / \mathrm{ha}$;

$P_{f}$ - the price of fertilizers (both organic and mineral), in rubles;

$R_{f}$ - the recommended fertilization rate, in $\mathrm{kg} / \mathrm{ha}$;

$C_{\text {til }}$ is the cost of tillage, which is defined as the expenses for tillage based on the technology of cultivation of agricultural crops, in rubles/ha;

$S$ is the land plot area, in ha.

The calculation of the lost profit is based on the termination of annual income generation for the users of withdrawn lands for the coming period, bringing the land plot to the state of maximum use efficiency; it should be calculated using the following formula:

$$
L P=\frac{Y \cdot C \cdot P \cdot S}{\left(1+\frac{R}{100}\right)}
$$

where:

$L P$ - the lost profit, in rubles;

$Y$ - the average crop yield on the farm over the last 5 years, in $\mathrm{q} / \mathrm{ha}$;

$\mathrm{C}$ - correction factors that take into account the duration of the period of restoration of the fertility of the land plot

$P$ - the price of one quintal of production at the time of temporary withdrawal from circulation of a land plot, in rubles;

$R$ is the refinancing rate of the Central Bank of the Russian Federation, in \%.

$S$ is the area of the temporarily withdrawn land plots, in ha.

The following table shows correction factors that take into account the duration of the period of restoration of the fertility of the land plot and the coefficients for recalculating the lost annual income; the value of such coefficients increases depending on the period for bringing the land plot into the state of maximum use efficiency (Table 1).

Table 1. Correction factors that take into account the duration of the period of restoration of the fertility of the land plot.

\begin{tabular}{|c|c|c|c|c|c|c|c|}
\hline Duration & Coefficient & Duration & Coefficient & Duration & Coefficient & Duration & Coefficient \\
\hline 1 year & 0.9 & 4 years & 3.2 & $8-10$ years & 5.6 & 21 to 25 years & 8.9 \\
\hline 2 years & 1.7 & 5 years & 3.8 & $11-15$ years & 7.0 & $26-38$ years & 9.3 \\
\hline 3 years & 2.5 & $6-7$ years & 4.6 & $16-20$ years & 8.2 & $\begin{array}{c}31 \text { years and } \\
\text { over }\end{array}$ & 10 \\
\hline
\end{tabular}

When calculating the lost profit, it is recommended to use the actual production volumes in terms of average size over 5 years according to the current prices at the time of land withdrawal from circulation. The seeding rate of seeds of perennial grasses is considered following the scientifically grounded farming system for the Omsk Region. When determining the composition of a grass mixture, the natural and climatic conditions, the location of the plot and the species composition of the natural vegetation (vegetation 
map) are taken into account. The application rate of organic fertilizers is determined by means of calculation, taking into account the loss of humus during the movement, land planning and storing of the fertile soil layer. The application rate of mineral fertilizers is taken into account as amounting to 4-5 q/ha, which is an increase of 1.5-2 times if compared with the scientifically grounded farming system adopted when growing crops on undisturbed soils. The cost of seeds of perennial grasses, mineral and organic fertilizers is applied according to the manufacturer's price list according to the current market price in the year of the assessment.

Thus, the formula for calculating the cadastral value while taking into account the environmental factor should look as follows:

$$
C V F L=\frac{\frac{Y_{r s} \cdot K_{s} \cdot A P}{A P_{b} \cdot K_{1} \cdot K_{2} \cdot K_{3} \cdot K_{4}} \cdot P-E_{C}-\left(\left(R_{s} \cdot P_{S}+R_{f} \cdot P_{f}+C_{t i l}\right) \cdot S+\frac{Y \cdot C \cdot P \cdot S}{\left(1+\frac{R}{100}\right)}+E_{\text {sur }}\right)}{R_{c}}
$$

The following scientific methods were applied in the research: calculation and graphic, analytical, constructive analytical methods. The methodological provisions elaborated above and the formula for calculating the cadastral value and scientific research methods allowed the authors to perform calculations for a specific land plot of agricultural land.

\section{Results and Discussion}

The test run of the above-described methodology was carried out on the land plot of the joint-stock company "Yuzhnoe", with cadastral number 55:12:0:1433, located in the Maryanovsky District of the Omsk Region on an area of 1,632,686 m2 (163 ha), area of the temporarily withdrawn land plots is 28 ha. The possessory right on the land plot of the joint-stock company "Yuzhnoye" is registered under the land category - agricultural land; type of permitted use - for agricultural production, namely: production and sale of agricultural crop seeds; cadastral value - 8,506,294.06 rubles; cadastral value per m2 - 5.21 rubles / $\mathrm{m} 2$.

The analysis of land use showed that the following negative processes are observed on the land plot: flooding occurs to a very strong degree, waterlogging to a strong degree, and paludification and erosion to a moderate degree. The development of these negative processes leads to a decrease in soil fertility by $20 \%, 18 \%, 13 \%$ and $15 \%$, respectively. The decrease in fertility is associated with an increase in the unit costs of maintaining the soil fertility, which amount to $13 \%, 11 \%, 8 \%$ and $9 \%$, respectively.

The calculation of the expenses for bringing the land plot to the state of maximum use efficiency was carried out in order to restore arable land with perennial grasses and is presented in Table 2 .

Table 2. The calculation of the expenses for bringing the land plot to the state of maximum use efficiency.

\begin{tabular}{|l|l|}
\hline \multicolumn{1}{|c|}{ Characteristics } & \multicolumn{1}{|c|}{ Information } \\
\hline $\begin{array}{l}E_{\text {sur }} \text { are the expenses for conducting an } \\
\text { agrochemical survey, in rubles }\end{array}$ & Not carried out \\
\hline$P_{s}$ is the price of seeds, in rubles/t & Mustard seeds: 60,000 \\
\hline $\begin{array}{l}R_{s} \text { is the recommended seeding rate of seeds, in } \\
\text { tha }\end{array}$ & 0.2 \\
\hline $\begin{array}{l}P_{f} \text { is the price of fertilizers (both organic and } \\
\text { mineral), in rubles }\end{array}$ & $\begin{array}{l}\text { Mineral: } 27,000 \\
\text { Organic fertilizer based on chicken }\end{array}$ \\
\hline
\end{tabular}




\begin{tabular}{|c|c|c|}
\hline & \multicolumn{2}{|l|}{ manure: 3,500} \\
\hline$R_{f}$ is the recommended rate of fertilization, in $\mathrm{t} / \mathrm{ha}$ & \multicolumn{2}{|l|}{0.4} \\
\hline \multirow{6}{*}{$C_{t i l}$ is the cost of tillage, in rubles/ha } & Labour remuneration & $1,044.8$ \\
\hline & $\begin{array}{l}\text { Ploughing the land with a } \\
\text { tractor }\end{array}$ & $5,053.6$ \\
\hline & Petrol, oil and lubricants & $1,879.1$ \\
\hline & Depreciation and maintenance & $2,247.9$ \\
\hline & Other expenses & 214.8 \\
\hline & General expenses & $10,440.2$ \\
\hline $\begin{array}{l}E_{r i} \text { are the expenses for restoring and improving } \\
\text { the fertility, in rubles }\end{array}$ & \multicolumn{2}{|l|}{$969,925.6$} \\
\hline $\begin{array}{l}S \text { is the area of the temporarily withdrawn land } \\
\text { plots, in ha }\end{array}$ & \multicolumn{2}{|l|}{28} \\
\hline $\begin{array}{l}Y \text { is the average crop yield on the farm over the } \\
\text { last } 5 \text { years, in } \mathrm{g} / \mathrm{ha}\end{array}$ & \multicolumn{2}{|l|}{41.1} \\
\hline $\begin{array}{l}P \text { is the price of one quintal of production at the } \\
\text { time of temporary withdrawal from circulation of a } \\
\text { land plot, in rubles }\end{array}$ & \multicolumn{2}{|l|}{1,550 as of $04 / 02 / 2021$} \\
\hline $\begin{array}{l}R \text { is the refinancing rate of the Central Bank of the } \\
\text { Russian Federation, in \% }\end{array}$ & \multicolumn{2}{|l|}{4.25 as of $04 / 02 / 2021$} \\
\hline$L P$ is the lost profit, in rubles & \multicolumn{2}{|l|}{$103,883.5$} \\
\hline $\begin{array}{l}E_{\text {eff }} \text { are the expenses for bringing the land plot to } \\
\text { the state of maximum use efficiency, in rubles }\end{array}$ & \multicolumn{2}{|l|}{$1,073,809.053$} \\
\hline Current cadastral value of the land plot, in rubles & \multicolumn{2}{|l|}{$8,506,294.06$} \\
\hline$C V F L$ is the cadastral value of the land plot & \multicolumn{2}{|l|}{$7,438,851$} \\
\hline
\end{tabular}

Restoration of the lost fertility of the arable land is recommended applying the green manure fallow system. The term for the restoration of the arable land is 2 years. The complex of works includes the execution of pre-sowing tillage, application of organic and mineral fertilizers, sowing of green manure in the first year; the ploughing of the resulting mass of grasses, which is a nitrogen accumulator, thereby enriching the soil, in the second year.

\section{Conclusions}

The above-described provisions for an improvement of the methodology of cadastral assessment of agricultural lands, the significance of these lands for the welfare of the state and the population, ensuring sustainable and rational land use by improving their natural potential, have determined the relevance and timeliness of the present scientific research.

The methodology proposed by the authors will allow an adjustment in the cadastral value of a land plot of agricultural land and, as a consequence, in the amount of land tax due.

It should be noted that there is no clear legislative regulation of relations due to the replenishment of losses of agricultural lands in agricultural production, withdrawn and used for purposes not related to agriculture in terms of compensation for expenses, no set of measures is provided for the restoration of agricultural lands and their quality. For this purpose, it is necessary to introduce at the legislative level a number of provisions concerning the regulation of relations on the use of agricultural lands, namely: to provide for the compensation of the expenses for improving and restoring fertility, among others from the state budget, as well as state support for reimbursing the expenses for introducing lands into the economic turnover.

The updated information on the quality characteristics of agricultural land plots based on the results of the preparatory stage of the cadastral assessment should be introduced into 
the United State Register of Real Properties and, if the draft of the law "On Land Management" enters into force, the use of agricultural regulations to develop proposals for improving the condition of lands should be guaranteed.

\section{References}

1. D. Valiev et al, IOP Conf. Ser.: Earth Environ. Sci. 579, 012139 (2020) doi:10.1088/1755-1315/579/1/012139

2. N. Zotikov et al, IOP Conf. Ser.: Earth Environ. 604, 012018 (2020). doi:10.1088/1755-1315/604/1/012018

3. K. Pawlak, M. Kołodziejczak, Sustainability 12(13), 5488 (2020) doi.org/10.3390/su12135488

4. D. Bubnov, Rational use of land resources as a factor of sustainable development of the region: dissertation for the degree of candidate of economic sciences (Volgograd, 2014)

5. Federal law "About state cadastre assessment" from 03.07.2016 N 237-FZ, http://www.consultant.ru/document/cons_doc_LAW_200504

6. V. Stukach, O. Dolmatova, O. Evdokhina, N. Starovoitova, Moscow journal 3, 154171 (2020) doi:10.24411/2413-046X-2020-10189

7. S. Volkov, S. Lipski, Land management, monitoring and cadastre 4, 5-10 (2018)

8. P.M. Sapozhnikov, Y.N. Filippova, O.D. Konyushkova, A.K. Ogleznev, Eurasian Soil Science 11, 1456-1462 (2019) doi:10.1134/S0032180X19090077

9. V. Makht, V. Rudi, N. Osintseva, Accounting and assessment of agricultural land by quality and types of use: monograph (2018) ISBN 978-5-6041558-5-1 